\title{
Level of Glucose, Cholesterol and Albumin of repeatedly breed Madura Cattle
}

\author{
Anggella T. Tombuku*, Ratri Retno Ifada \\ Balai Pengkajian Teknologi Pertanian Sulawesi Utara, Ministry of Agriculture, Indonesia
}

\begin{abstract}
The current research aims to know the level of glucose, cholesterol and albumin of repeatedly breed Madura cattle. This research conducted in Madura Island for taking the blood sample. This research used 10 Madura cattle, the 5 cattle experiencing the repeated breeding and the 5 others are in the fertile condition. The results show that the glucose level of the repeated breeding cattle was higher, which was about $(73.28 \pm 10.26 \mathrm{mg} / \mathrm{dl})$ compared to the fertile cattle $(69.96 \pm 20.23 \mathrm{mg} / \mathrm{dl})$. Different from the total cholesterol of the repeated breeding cattle which was lower, it's about $(132.02 \pm 26.43 \mathrm{mg} / \mathrm{dl})$ compared to the fertile cattle $(135.28 \pm 24.83 \mathrm{mg} / \mathrm{dl})$ using t-student analysis. Besides, the albumin level of the repeated breeding Madura cattle is lower, which was about $(4.61 \pm 0.13 \mathrm{~g} / \mathrm{dl})$ compares to the fertile cattle which is about $(5.26 \pm 0.44$ $\mathrm{g} / \mathrm{dl})$. Based on the gathered data, there are no significant data but the level of the total cholesterol and the albumin of the blood in Madura cattle that experiencing the repeated breeding were lower than the fertile cattle. The high glucose level of the repeated breeding cattle was higher than the normal level of the common fertile cattle.
\end{abstract}

\section{Introduction}

The successful of the stockbreeding business can be seen from the improvement of the livestock population raised. The improvement effort must be supported by the good management. The poor management affects the low efficiency of the cattle reproduction. Providing the good quality feed and the good environment can support the reproduction performance of the beef cattle so that it can complement the nutrient requirement for the physiological process and the reproduction of the cattle.

Madura cattle coming from the Madura Island, Indonesia which potential local cattle to be developed. Madura cattle have advantages that are adaptive, have good fertility, resistant to disease [1] and have weighs birth about $20.55 \mathrm{~kg}$ [2]. Characteristic of Madura cattle are small body and horns than the Balinese cattle. Sapudi Island is location to purify the Madura cattle [3].

Madura cattle are bred in a natural way and artificial insemination. One of the reproductive disorders is repeated breeding. The repeated breeding shows that the cattle experiencing the failure in the reproduction performance. The repeated breeding is a female cattle condition which fails to pregnant after being breeding three times or more spaces

* Corresponding author: anggellatombuku@gmail.com 
services in the absence of detectable abnormality. Repeated breeding is influenced by several factors including genetics of male, female, environmental and management [4].

The fertility failure can be caused by the anatomic abnormalities of the reproduction tract, the abnormalities of ovum and spermatozoa, and the ovulation and the cysts ovarium failure. The other causes are the early embryotic death caused by the infection of the reproduction tract, the existence of certain disease and the presence of hormonal disorder. Generally, the cattle that experiencing the repeated breeding marked by the length of the calving interval (18-24 months), the low number of conception $(<40 \%)$, and the heights of the service per conception ( $>3$ ) [5]. The heights repeated breeding will affect the low production and productivity of the cattle per year. The low nutrient feed can indicate the cattle to experience the repeated breeding. Therefore, in the efforts to improve the reproduction performance, the cattle feed nutrient status must be considered because it will influence the blood biochemical nutrient of the cattle, such as the glucose, cholesterol, and the albumin.

One of the ways to know the reproduction status of the Madura cattle is by observing the level of glucose, cholesterol, and albumin. The low level of the glucose can influence the energy produced by the cattle which affecting the fertility failure. Same as the heights cholesterol and albumin, it can influence the equality of the energy which affecting the fertility degradation and extends the anesthetic period. Besides the genetic and the environmental factors, the nutrient factor also indeed influences in improving the reproduction performance so that it really need to be considered and needing the good management. This research aims to determine the difference between the blood biochemical profile of Madura cattle that experienced repeated breeding and fertile cattle.

\section{Methodology}

This research was conducted on Madura Island for taking blood sample. Samples of cholesterol, albumin, and glucose were analyzed in the integrated research and testing laboratories, Gadjah Mada University Yogyakarta. The materials used in this research were 10 cattle from the farm of the people consists of 5 fertile cattle and the 5 others are the cattle had been in the insemination or ever breeding naturally more than three times but there were no birth signs. Age around 3-5 years, normal reproduction, been breed at least once with a healthy body condition.

\section{Results and Discussion}

Result of the glucose, cholesterol, and albumin are shown in the Table 1.

Table 1. The testing result of the blood biochemical

\begin{tabular}{|l|c|c|}
\hline Parameters & $\begin{array}{c}\text { Fertil (n=5) } \\
\text { (mg/dl) }\end{array}$ & $\begin{array}{c}\text { Repeated Breeding } \\
\text { (mg/dl) }\end{array}$ \\
\hline Glucose & $69.96 \pm 20.23$ & $73.28 \pm 10.26$ \\
\hline Cholesterol & $135.28 \pm 24.83$ & $132.02 \pm 26.43$ \\
\hline Albumin & $5.26 \pm 0.44$ & $4.61 \pm 0.13$ \\
\hline
\end{tabular}

Results of the glucose level are shown that repeated breeding have the higher than the fertile cattle. The glucose level of the blood serum in the cattle which experiencing the repeated breeding more than of the normal level, which is about 46-60 mg/dl [6]. Fertile level is above normal level because in this research, the repeated breeding and fertile cattle not much different of the Body Condition Score; 3-4 on the 1-5 scale. Repeated breeding have more level caused the obesity factor which indeed influencing in the reproduction 
process. Based on [7], if the cattle have the body weight more than the ideal weight, the cattle will have the reproductive disorder and the metabolism disease. It also occurs if the cattle have less than ideal weight, it will affect the reproductive system. 205 days of age from weaning weight, 365 days of age of yearling weight were $97.00 \pm 13.77 \mathrm{~kg}$ and $120.00 \pm 10.86 \mathrm{~kg}$ [8] and then have service per conception (1.46 time), conception rate $(58.80 \%)$ and gestation length $(283.35 \pm 17.15$ days) [9]. When the intake carbohydrate in the form of glucose over than needed, the over glucose will be changed into the calories which causing the disturbance to the reproduction apparatus and impacting to the occurrence of the repeated breeding. According to [10], state that the overfeed in a long time can cause the disturbance of the reproductive process of female cattle. The disturbance of the reproductive process causes by the fat deposits around the ovarium and burst ovary which causes the ovulated ovum hindered to enter the fallopian tubes thus there is no fertilization process occurs.

Glucose level testing on the repeated breeding cattle and the fertile cattle, it gained that the low average cholesterol level of the repeated breeding cattle (table 1). Based on [11], Cholesterol levels in horned cows and polled cows were $78.76 \pm 27.50 \mathrm{mg} / \mathrm{dl}$ and $64.87 \pm 25.46 \mathrm{mg} / \mathrm{dl}$ respectively. According to [11] total cholesterol of dairy cows in fertile condition around $166,08 \pm 37,06$ and repeated breeding $124,59 \pm 34,73$. The low cholesterol level of the repeated breeding cattle is still in the normal range. The not enough far difference caused by the feed given are not a far difference between one cattle and the others. Therefore, the fat content of the feed is also not too far difference. If the consumption of the cholesterol is over, it can increase the cholesterol level in the blood and if it is less, it can push the lust and the ovulation or reduce the total ovum ovulated [12]. State that cholesterol is the important element in the membrane plasma and the parental compound for the other steroid elements synthesized in the body like cortex hormone adrenaline, sex hormone, vitamin D, the bile acid [13].

The research result shows that the albumin level of the Madura Cattle blood serum which experiencing the repeated breeding is lower than the normal cattle. This clear differentiation shows that the low level of albumin causes the repeated breeding. Albumin levels in infertile bali cattle around 3.10-3.60 g/dl and fertile 3.2-4.2 g/dl [14]. Based on [15], the less albumin causes the occurrence of the low lust, quite a lust, anestrus, repeated breeding, early embryonic death, and embryos absorption that die by the uterus wall. Another function of albumin is due to its role in removing the nutrient process that is transporting the small molecules through the plasma and the cell fluids. Therefore, a normal BCS will affect the average albumin concentration [16]. This function is closely related to the free fatty acid metabolism, bilirubin and some types of the drugs that are less soluble in the water but must be carried through the blood from one organ to the others so that is can be metabolized or excreted. The lower the albumin level, the nutrient from the feed cannot be used maximally [17].

\section{Conclusions}

Cholesterol and the albumin level of Madura cattle with the repeated breeding condition were lower than the fertile cattle. And then the high glucose level of the repeated breeding cattle was higher than the normal level of the common fertile cattle.

\section{References}

1. M. Zali, A.Y. Heryadi, S. Nurlaila, Z. Fanani, Madura Cattle Agribusiness Performance and Feasibility in Galis Region, Madura. J. Int. Adv. Multidiscip. Res. 5 (2018) 
2. Hartatik, T.S.D. Volkandari, Sumadi, Relatedness Between Polymorphism Growth Hormone Gene and Growth Traits of Limousin Cross Madura cattle. Proceedings of the $15^{\text {th }}$ AAAP Animal Science Congres. (2012)

3. N. Ngadiyono. Beternak Sapi Potong. PT Intan Sejati, Klaten. 23 (2012)

4. H. B. Wodaje, T.A. Mekuria. Risk Factors of Repeat Breeding in Dairy Cattle. Advances in Biological Research. 4 (2016)

5. B. Rustamadji, Ahmadi, Kustono, and Sutarno T. 2007. Kinerja usaha peternakan sapi perah rakyat sebagai tulang punggung pembangunan persusuan nasional. Proceedings of Persusuan Nasional. Yogyakarta. Dies 38 Fapet UGM. (2007)

6. D.P. Rahardja. Strategi Pemberian Pakan Berkualitas Rendah (Jerami Padi) Untuk Produksi Ternak Ruminansia. Dinas Peternakan Makassar (2008)

7. A.M. Budiawan, N. Ihsan, S. Wahjuningsih. Hubungan Body Condition Score Terhadap Service Per Conception Dan Calving Interval Sapi Potong Peranakan Ongole Di Kecamatan Babat Kabupaten Lamongan. J. Ternak Tropika 1 (2015)

8. I. Sulistiyoningtiyas, V.M.A. Nurgiartiningsih, G. Ciptadi. Evaluation of performance for body weight and vital statistic of Madura cattle based on year of birth. JIPT, 2 (2017)

9. F. Kutsiyah, Kusmartono, T. Susilawati. Comparative study of the productivity of Madura cattle and its crossbred with Limousin in Madura Island. JITV, 2 (2003)

10. D. Ratnawati, C.P. Wulan, A.S. Petunjuk Teknis Penanganan Gangguan Reproduksi Pada Sapi Potong. Pusat Penelitian Dan Pengembangan Peternakan Badan Penelitian Dan Pengembangan Pertanian Departemen Pertanian. Loka Penelitian Sapi Potong. Grati Pasuruan (2007)

11. S.A. Prihatno, A. Kusumawati, N.W.K. Karja. Blood Biochemical Profile in Repeat Breeding Dairy Cows. J. Vet Med. 1 (2013)

12. F. Yudha, A. Nuzul, A. Siti, R.Y. Fitri, E. Erina, A. Faridha, A. Azhar. Profile of Haematology and Biochemistry of Aceh Polled and Horned Cow. EDP Sciences 151 (2020)

13. Murray R K, Granner and Rodwell. Biokimia Harper. Penerjemah : Andry Hartono , EGC : Jakarta. (2003)

14. A.S. Drajat, Dahlanuddin, M. Ali, Imran, Lestari, Maskur. Pemberian Pakan, Pemeliharaan dan Gambaran Darah pada Sapi bali (Bos sondaicus) Infertil. Proceedings Seminar Nasional Pengembangan Sapi Bali Berkelanjutan dalam Sistem Peternakan Rakyat, Mataram, (2009)

15. H.J. Bearden, J.W. Fuquay, S.T. Willard. Applied Animal Reproduction. 6th ed. Pearson Prentice Hall, USA (2008)

16. I.Z. Irfan, A. Esfandiari, C. Choliq. Profil protein total, albumin, globulin dan rasio albumin dan globulin sapi pejantan bibit. JITV. 2 (2014)

17. Roche, Rondeau, S. Ranjan, Tarnus, Bourdon. The antioxidant propertis of serum albumin. Laboratoire de Biochimie et Genetique Moleculaire (LBGM), Universite de La Reunion, Saint Denis de La Reunion, France (2008) 